\title{
Estimating chilling duration from daily temperature extremes and elevation in Israel
}

\author{
Robert Aron $^{1}$, Zipora Gat $^{2}$ \\ ${ }^{1}$ Department of Geography, Central Michigan University, Mt. Pleasant, Michigan 48859, USA \\ ${ }^{2}$ Division for Agricultural Meteorology, Israel Meteorological Service, Bet-Degan, 50-250 Israel
}

\begin{abstract}
Deciduous plants require chilling temperatures in winter in order to complete the rest phase of dormancy and to enable normal renewed growth. Models were developed from limited Israeli records of hourly temperatures for estimating chilling temperatures at more widely available stations recording maximum and minimum temperatures. Models and maps were created not only for the traditional definition of chilling temperatures, i.e. hours below $7.2^{\circ} \mathrm{C}$, but also for hours below $8.4^{\circ} \mathrm{C}$ and $10.4^{\circ} \mathrm{C}$. These data will be useful for both operational care and planning future plantings of deciduous crops.
\end{abstract}

\section{INTRODUCTION}

For a plant to grow successfully in a given area, it must be adjusted to the local climate. Regions where a crop can be successfully produced are often tested through trial and error which, in many cases, results in great losses. Greater knowledge concerning the physical environment may reduce errors and miscalculations. Mid-latitude deciduous plants require cool (chilling) temperatures during the dormant phase of their growth cycle in order to begin renewed growth in spring. The amount of exposure to chilling temperatures is an important aspect of the climate in determining warm or cold winter boundaries for successful deciduous fruit and nut production, and can strongly affect production near those boundaries.

In the fall, deciduous plants become dormant. This period can be divided into 3 phases: pre-rest, rest, and post-rest. During the pre-rest phase, buds will no longer actively grow in response to favorable conditions but can be easily 'forced' by subjection to cold or heat, exposure to long photoperiods, nitrogen fertilization, application of gibberellic acid, or shock treatments. Under natural circumstances, with shortening photoperiods and no physical or chemical shocks, deciduous trees will make physiological changes, finally reaching a state of rest. During this phase, only the most drastic treatments will stimulate an active growth response and even this response will be weak as compared with either pre- or post-rest growth responses. It is during this phase of the plant's growth cycle that chilling temperatures are required to promote both hormonal and physical changes in the buds. When the plant's chilling requirement has been satisfied, the rest phase of the plant's growth cycle is completed and the plant is ready for renewed growth. In some seasons the chilling requirement of a plant may have been met before the onset of warm temperatures. In this case the actual time of the bud's renewed growth and break will be determined by rising temperatures in spring. In these seasons frost, after a warm period, may pose a threat. Imposed dormancy or postrest is the period after rest is completed and dormancy is continued by the lack of warm temperatures. If chilling is incomplete during the rest phase of the bud's development, the total inhibition that existed earlier may not have been removed. Without appropriate countermeasures, only a limited amount of activity may be possible with spring warming. Since the timing of bud break in spring is a function of the winter chilling regime, it is important to have a good estimate of this accumulation to determine if and what type of countermeasures may be needed.

While considerable research has been undertaken in Isreal regarding chilling, the lack of knowledge about the distribution of chilling temperatures throughout Israel has resulted in the planting of some varieties in areas where they are unsuited and/or production is below expectations.

Methods for estimating chilling temperatures have 
been developed for a number of areas (Butson \& Gerber 1964, Demaria 1969, Aron 1971, Richardson et. al. 1974, Sanders 1975, Aron 1983). This paper presents a model for estimating and evaluating a plant's exposure to chilling temperatures in Israel, Judea and Samaria, taking into account temperature extremes, elevation, and local topography.

\section{SELECTION OF CRITERIA FOR CHILLING TEMPERATURES}

Various temperature criteria have been used to study the relationship between low temperatures and the breaking of rest. The most widely used of these low temperature measures (which may have first been suggested by Hutchins in 1932 (Weinberger 1950), is the number of hours during which the temperature is $7.2^{\circ} \mathrm{C}$ $\left(45^{\circ} \mathrm{F}\right)$ or lower. Cooper (1953) found that there was some bud activity in peaches at 0.6 and $8.9^{\circ} \mathrm{C}(33$ and $48^{\circ} \mathrm{F}$ ), but in both cases it was slight. He thus chose 1.7 and $7.2^{\circ} \mathrm{C}\left(35\right.$ and $45^{\circ} \mathrm{F}$ ) as the most reliable temperature criteria for measuring rest-breaking chilling. Brown (1960), working with apricot flower buds, found that temperatures between 4.4 and $7.2^{\circ} \mathrm{C}\left(40\right.$ and $\left.45^{\circ} \mathrm{F}\right)$ were the most efficient for breaking rest. He also found that temperatures between 1.7 and $4.4^{\circ} \mathrm{C}$ ( 35 and $40^{\circ} \mathrm{F}$ ) and between 7.2 and $10.0^{\circ} \mathrm{C}\left(45\right.$ and $\left.50^{\circ} \mathrm{F}\right)$ were less effective, and that temperatures under $0^{\circ} \mathrm{C}\left(32^{\circ} \mathrm{F}\right)$ or over $10.0^{\circ} \mathrm{C}\left(50^{\circ} \mathrm{F}\right)$ generally had a negative effect on bud break. He found little effect with temperatures between 0 to $1.7^{\circ} \mathrm{C}\left(32\right.$ to $\left.35^{\circ} \mathrm{F}\right)$. Lamb (1948), however, found that the initial effect of temperatures below freezing $\left(-3.0^{\circ} \mathrm{C}\right)$ was to retard the breaking of rest, but when temperatures were kept at a constant $-3.0^{\circ} \mathrm{C}$, rest was broken as rapidly as at higher temperatures.

Erez \& Lavee (1971) found that temperatures from 2.7 to $6.1^{\circ} \mathrm{C}\left(37\right.$ to $\left.43^{\circ} \mathrm{F}\right)$ showed an effect similar to that of $6.1^{\circ} \mathrm{C}\left(43^{\circ} \mathrm{F}\right)$. However, they found that chilling efficiency gradually decreased to about one half with a rise in temperature from about 6.1 to $10.0^{\circ} \mathrm{C}\left(43\right.$ to $\left.50^{\circ} \mathrm{F}\right)$. Chandler (1957), Sharpe \& Parker (1963), Weinberger (1967), and Westwood \& Bjornstad (1968) also noted that temperature around 7.2 to $10.0^{\circ} \mathrm{C}\left(4.5\right.$ to $\left.50^{\circ} \mathrm{F}\right) \mathrm{had}$ at least some effect in breaking rest.

Gurdian \& Biggs (1964) found that in peaches with very low chilling requirements such as 'Okinawa', 'Flordawon', and 'Flordahome', higher temperatures were also effective in breaking rest. They found that exposure to temperatures at $12.8^{\circ} \mathrm{C}\left(55^{\circ} \mathrm{F}\right)$ were as effective as $7.2^{\circ} \mathrm{C}\left(45^{\circ} \mathrm{F}\right)$. In testing 'Nemaguard', which has a low chilling requirement among peaches in general but higher than the aforementioned 3 peach varieties, they found that a temperature of $7.2^{\circ} \mathrm{C}\left(45^{\circ} \mathrm{F}\right)$ was significantly more effective than $12.8^{\circ} \mathrm{C}\left(55^{\circ} \mathrm{F}\right)$ in the breaking of buds and in increasing the percentage of buds resuming growth. Weinberger (pers. comm. 1973) stated that the use of $7.2^{\circ} \mathrm{C}\left(45^{\circ} \mathrm{F}\right)$ as a measure of the amount of chilling a plant has received is based on mainline varieties, but for varieties requiring considerably less chilling, higher temperatures are quite effective. More recently, Erez \& Couvillon (1987) have stated that the optimum temperature for satisfying the chilling requirement is $8.0^{\circ} \mathrm{C}$. Erez (pers. comm. 1988) has further suggested that temperatures between 8.5 to $10.4^{\circ} \mathrm{C}$ are about half as effective in breaking rest as those below $8.4^{\circ} \mathrm{C}$

In conclusion, most researchers (Bennett 1950, Weinberger 1950, 1956, 1967, Black 1953, Samish 1954, Brown 1958, Sharp \& Parker 1963, Tabuenca et al. 1972, Sanders 1975, Aron 1983, and others) have traditionally used hours under $7.2^{\circ} \mathrm{C}$ as a measure of the amount of chilling a plant has received. Increasing evidence, however, seems to support the belief that temperatures between 7.2 and $10.0^{\circ} \mathrm{C}$ may, at least, be somewhat effective in breaking rest. Furthermore, it seems that in deciduous fruit and nut trees with very low chilling requirements, temperatures as high as $12.8^{\circ} \mathrm{C}$ may be equally as effective as $7.2^{\circ} \mathrm{C}$ in breaking rest. It appears to be the general rule that the lower a plant's chilling requirement, the higher the maximum temperature effective for breaking rest. Very low chilling varieties, however, account for only a minute percentage of the total crop acreage and production. To obtain the best estimates of chilling temperatures in Israel, it was decided to create 3 models with accompanying maps. The first uses the traditional hours below $7.2^{\circ} \mathrm{C}$ for estimating chilling. It allows the distribution of chilling temperatures in Israel to be directly compared with those in different parts of the world (Aron 1983, Sanders 1975, Demaria 1969, etc.). The second uses the hours below $8.4^{\circ} \mathrm{C}$ for estimating available chilling, It is based upon the findings of Erez \& Couvillon (1987) and Gilreath \& Buchanan (1981) that the optimum temperature for satisfying chilling is $8.0^{\circ} \mathrm{C}$. The third uses the hours below $8.4^{\circ} \mathrm{C}$, together with half the hours between 8.5 to $10.4{ }^{\circ} \mathrm{C}$, for estimating available chilling. It is based on many researchers' findings that temperatures up to approximately $10.0^{\circ} \mathrm{C}$ have some effect in breaking rest. Erez (pers. comm 1988), for example, believes that temperatures from 8.5 to $10.4{ }^{\circ} \mathrm{C}$ are about half as effective in breaking rest as temperatures at or below $8.4^{\circ} \mathrm{C}$.

\section{METHODS}

\section{Purpose of the model}

Five weather stations within Israel recorded hourly temperatures during some or all of the period from 
1978 to 1987 . From these data the actual number of hours per day below selected temperature levels could be determined. This was an inadequate number of observations to determine the distribution of chilling hours throughout the study area. However, a relatively complete record of maximum and minimum temperatures for 1971 to 1980 exists from 44 sites throughout the area. Thus models for estimating hours of chilling for the latter stations were derived using data from the 5 stations that record hourly temperatures. These models were then employed to estimate the chilling available at the 44 stations at which only maximum and minimum temperatures are available.

\section{Model development procedure}

The data were carefully checked for each temperature threshold for errors, outliers, and trends using scatter plots. All questionable observations were eliminated. Days with an excessive number of missing hourly observations were also eliminated. In addition, daily observations with 0 or $24 \mathrm{~h}$ below selected temperatures were eliminated (from maximum and minimum temperatures it can easily be determined if all or none of a given day's temperatures are above or below selected levels). These elimination procedures resulted in the retention of 497 observations for the model estimating temperatures below $7.2^{\circ}, 682$ observations estimating temperatures below $8.4^{\circ} \mathrm{C}$, and 1113 observations estimating temperatures below $10.4^{\circ} \mathrm{C}$.

The dependent variable was the number of hours below the desired temperature threshold $(7.2,8.4$ or $10.4^{\circ} \mathrm{C}$ ). The independent variables considered were daily maximum and minimum temperatures, day length, sun angle, month of the year, and transformed variables. Transformations were made by analyzing the scatterplots and the expected distribution of the daily temperature pattern. The transformations considered were $\min ^{2}, \min ^{3}, \max ^{2}, \max ^{3},(7.2-\min ) / R,(8.4$ - $\min ) / R,(10.4-\min ) / R$, and quadratic transformations of the last 3 , where min and max are the minimum and maximum temperatures and $R=\max -\min$ and the constants $7.2,8.4$ and 10.4 are the critical temperatures used in determining the dependent variable.

Linear models were then fitted in which the parameters were estimated by least squares. The predictors included in the model were chosen with the aid of a stepwise screening process incorporated into the regression program. At each step, another independent variable was included if it had a significant $F$ value (0.01 level). Among those that did, the one resulting in the greatest reduction of the sample standard deviation of the residual was selected. The process was stopped when no additional significant variable could be found.
To validate the procedure, $20 \%$ of the observations were removed at random and the constants re-estimated using the remaining data. The new equation was then used to predict hours of chilling for the observations previously set aside. The standard error of these predictions for the $20 \%$ subsample showed no significant difference from what would have been expected from the deviation about the regression line in the $80 \%$ subsample.

\section{Estimating procedure}

The 44 stations with relatively complete records of maximum and minimum temperatures did have a few cases with days, and even fewer cases of entire months, with missing observations. If, in a given month, up to $10 \mathrm{~d}$ maximum and minimum temperatures were missing, the average number of hours of chilling per day that occurred for that month was assumed to occur on those days. In the very few cases where an entire month's maximum and minimum temperatures were missing, that month's number of chilling hours was assumed to be the average for that month for the period 1971 to 1980 .

\section{RESULTS}

Three equations were derived for estimating the number of hours of chilling. The first of these was for hours at or below $7.2^{\circ} \mathrm{C}$.

$$
N=1.9+21.75 B
$$

where $N=$ number of chilling hours during the period; $B=\left[\left(7.2-T_{\min }\right) /\left(T_{\max }-T_{\min }\right)\right] ; T_{\min }=$ minimum temperature on a given day; $T_{\max }=$ maximum temperature for that day.

The coefficient of correlation (R) between the actual and predicted hours below $7.2^{\circ} \mathrm{C}$ for Eq. (1) was 0.908 . The amount of chilling available at the 44 stations recording maximum and minimum temperatures was then estimated using Eq. (1) and mapped for the period from November 1 to March 10 (Fig. 1). Any day with a minimum temperature above $7.2^{\circ} \mathrm{C}$ was assumed to have zero hours of chilling. If the maximum temperature was $7.2^{\circ} \mathrm{C}$ or below, the day was assumed to have $24 \mathrm{~h}$ of chilling. Isolines were interpolated between stations based upon elevation, distance from the sea, and rate of nocturnal radiation cooling (taken in part from the Frost Atlas of Israel (Lomas et al. 1989).

The second equation was derived for estimating hours at or below $8.4^{\circ} \mathrm{C}$.

$$
N=1.0+22.65 B+0.159 T_{\min }
$$




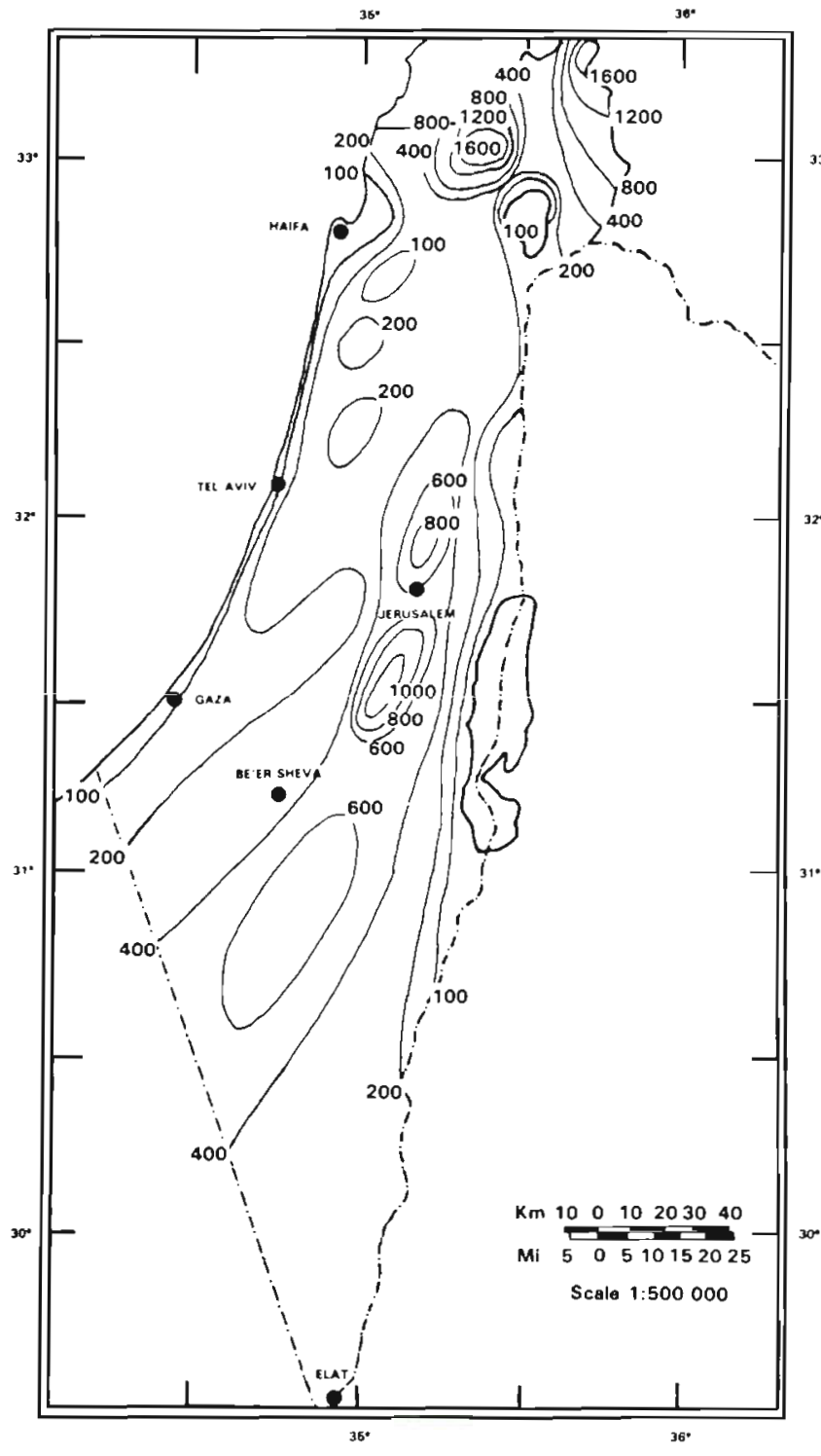

Fig. 1. Mean annual number of hours $7.2^{\circ} \mathrm{C}$ and below in the study area

where all variables have the same definitions as in Eq. (1), except $B=\left[\left(8.4-T_{\min }\right) /\left(T_{\max }-T_{\min }\right)\right]$.

The coefficient of correlation (R) between the actual and predicted hours below $8.4{ }^{\circ} \mathrm{C}$ was 0.892 . The amount of chilling available at the 44 stations recording maximum and minimum temperatures was then estimated using Eq. (2) and mapped (Fig. 2) using the same procedures and time periods as in Fig. 1.

The third equation was derived for estimating hours at or below $10.4{ }^{\circ} \mathrm{C}$. Hours below $8.4^{\circ} \mathrm{C}$ were given full weight, while hours with temperatures from 8.5 to $10.4^{\circ} \mathrm{C}$ were counted as only half as effective.

$$
\mathrm{N}=13.5+8.77 B-0.82 T_{\min }-0.2 T_{\max }
$$

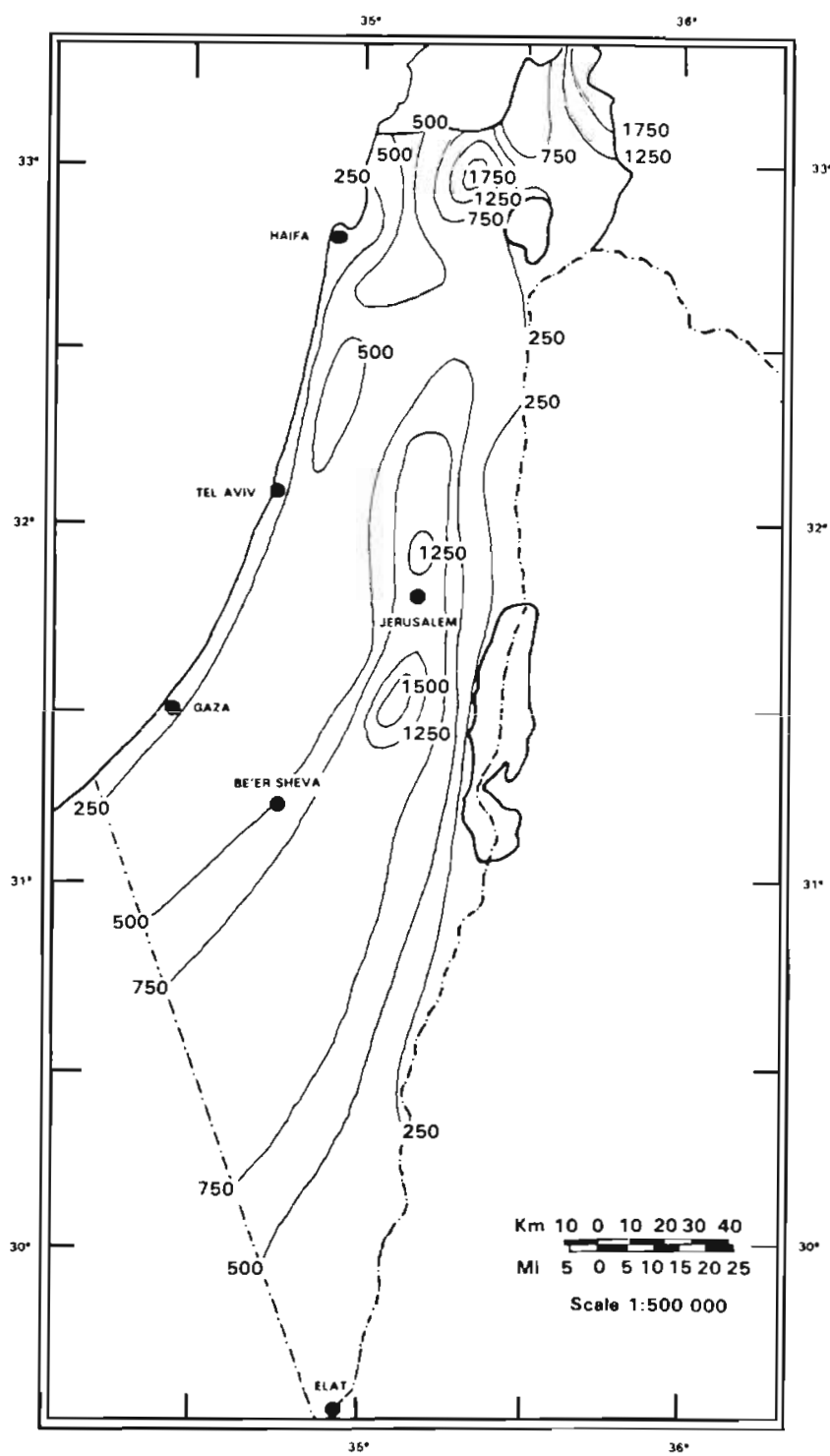

Fig. 2. Mean annual number of hours $8.4^{\circ} \mathrm{C}$ and below in the study area

where all variables have the same definitions as in Eq. (1), except $B=\left[\left(10.4-T_{\min }\right) /\left(T_{\max }-T_{\min }\right)\right]$.

The coefficient of correlation (R) between the actual and predicted hours was 0.923 . The amount of chilling available at the 44 stations was then estimated using Eq. (3) and mapped (Fig. 3) using the same procedures and time periods as in Fig. 1.

\section{DISCUSSION}

In developing the models for estimating chilling is the study area, relationships between hours of chilling and maximum and minimum temperatures were plot- 


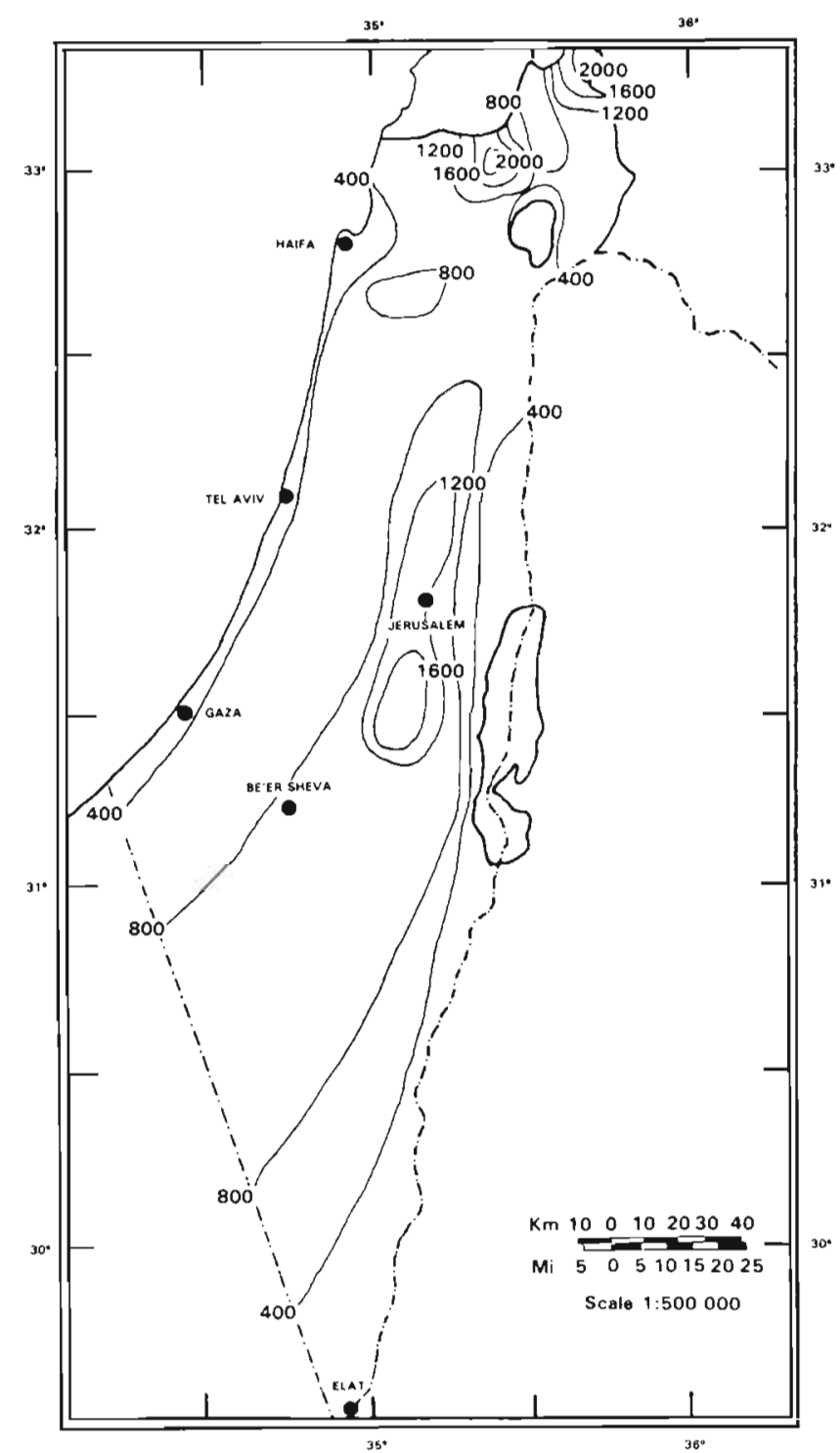

Fig. 3. Mean annual number of hours $10.4^{\circ} \mathrm{C}$ and below in the study area

ted. Analysis of these plots suggested many transformations of the data, including natural log, log base 10 , square roots, and quadratic. The only transformation that proved significant, however, was first suggested by Griffiths (1960) and employed by Aron (1971, 1975, 1983) for estimating chilling hours in California and by Sanders (1975) for estimating chilling hours in Georgia [Chilling Hours $=($ Temperature threshold - Minimum temperature)/(Maximum temperature - Minimum temperature)]. In both Georgia and California, however, quadratic transformations of the basic transformation proved very significant in explaining the residual error. An analysis of the plotted data suggested this might also be the case in our area. However, no quadratic transformations of this type on the Israeli data significantly reduced the residual error of the basic model.

With respect to the distribution of chilling hours, all 3 maps (Figs, 1, 2 \& 3) show the highest values of chilling hours in the mountains of Upper Galilee and the Golan Heights in the north. The lowest values of chilling hours appear along the longitudinal borders of the country, to the west along the Mediterranean coast, and to the east along the Jordan Rift Valley. On all 3 maps, the longitudinal mountain ranges from the very north to the south have a high number of chilling hours, including the mountains of upper and lower Galilee, Samaria, Judea, Hebron and Negev. The steepest gradients of chilling hours appear in Upper Galilee and the Golan Heights, and along the eastern side of the mountains facing the Jordan Valley, and are caused by abrupt topographical changes.

The relationship between the number of hours of chilling and elevation is further demonstrated in Figs. 4 \& 5. They compare the estimated number of hours below $7.2^{\circ} \mathrm{C}$ with elevation and geographical location by using 2 cross sections. The northern cross section (Fig. 4) is from west to east and the central cross section is from west to east to northeast (Fig. 5). Both cross sections extend from the Mediterranean Sea to the Jordan Rift Valley (Fig. 6). Fig. 7 and Table 1 compare the calculated chilling hours at the 3 thresholds to elevation. While the 8.4 and $10.4{ }^{\circ} \mathrm{C}$ curves estimating variations of the number of chilling hours with height are parallel, the $7.2^{\circ} \mathrm{C}$ curve increases at a less steep rate. Thus there is an increasing deviation of the $7.2{ }^{\circ} \mathrm{C}$ curves from the 2 other curves as the elevation and the amount of chilling hours increase. It seems that for the $8.4{ }^{\circ} \mathrm{C}$ and $10.4^{\circ} \mathrm{C}$ estimates, increasing values are primarily related to elevation. The $7.2^{\circ} \mathrm{C}$ curve appears to be more strongly affected by hours occurring during nights with radiational cooling. These are more frequent in the low-lying areas.

\section{CONCLUSION}

Many climatic factors affect the regions where a crop can grow. For deciduous crops one factor that can affect productivity is its exposure to chilling temperatures during its dormant phase.

The 3 equations and resulting maps (Figs. 1, 2 \& 3) provide an important tool for agricultural planners, horticulturists and researchers. These equations and maps should be of assistance in site and varietal selection as well as aiding in determining if and when countermeasures may be needed during years with below normal chilling.

At any given location the initial estimate should be adjusted for elevation with the equations from Table 1. 


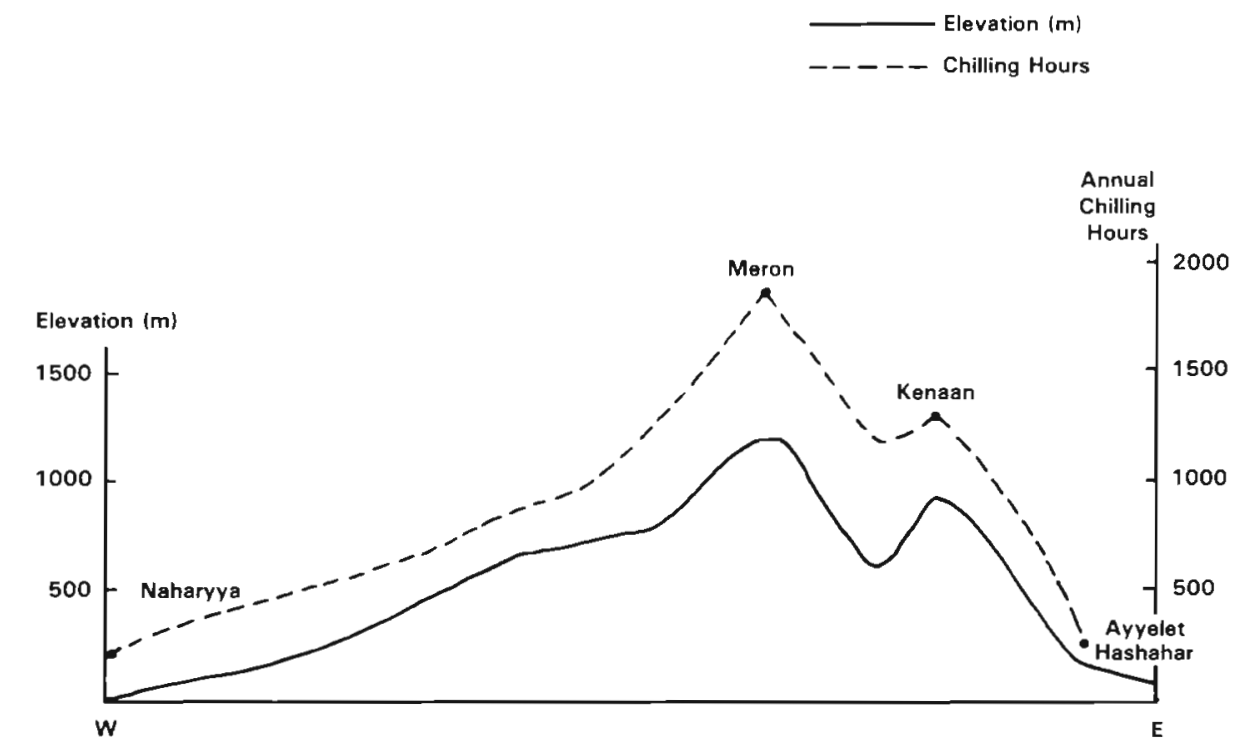

Fig. 4. Cross sections of chilling hours $\left(7.2^{\circ} \mathrm{C}\right)$ and elevation across northern Israel

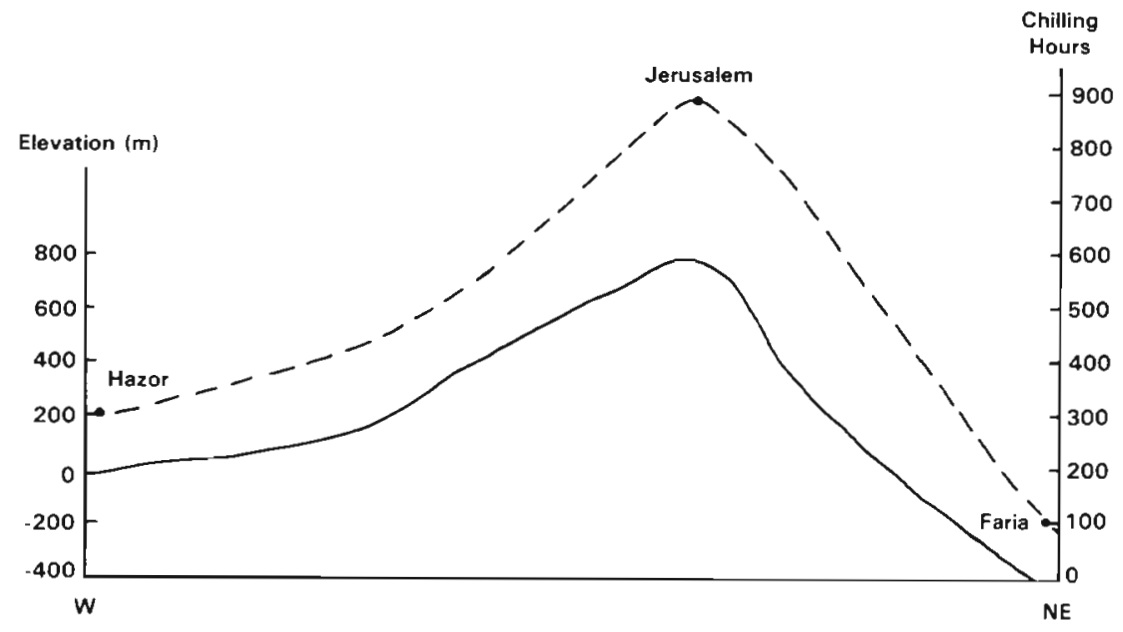

Fig. 5. Cross sections of chilling hours $\left(7.2^{\circ} \mathrm{C}\right)$ and elevation across central Israel

Table 1. Variation of chilling hours with changes in elevation (m)

\begin{tabular}{|c|c|c|c|c|}
\hline $\begin{array}{l}\text { Temperature } \\
\text { threshold }\end{array}$ & $\begin{array}{l}\text { Correlation } \\
\text { coefficient }\end{array}$ & Equation & $\begin{array}{c}\text { Level of } \\
\text { significance }\end{array}$ & $\begin{array}{c}\text { No. of } \\
\text { observations }\end{array}$ \\
\hline $7.2^{\circ} \mathrm{C}$ & 0.859 & $165.37+0.922$ (Height) & 0.01 & 46 \\
\hline $8.4^{\circ} \mathrm{C}$ & 0.904 & $317.74+1.139$ (Height) & 0.01 & 46 \\
\hline $10.4^{\circ} \mathrm{C}$ & 0.915 & $504.47+1.121$ (Height) & 0.01 & 46 \\
\hline
\end{tabular}




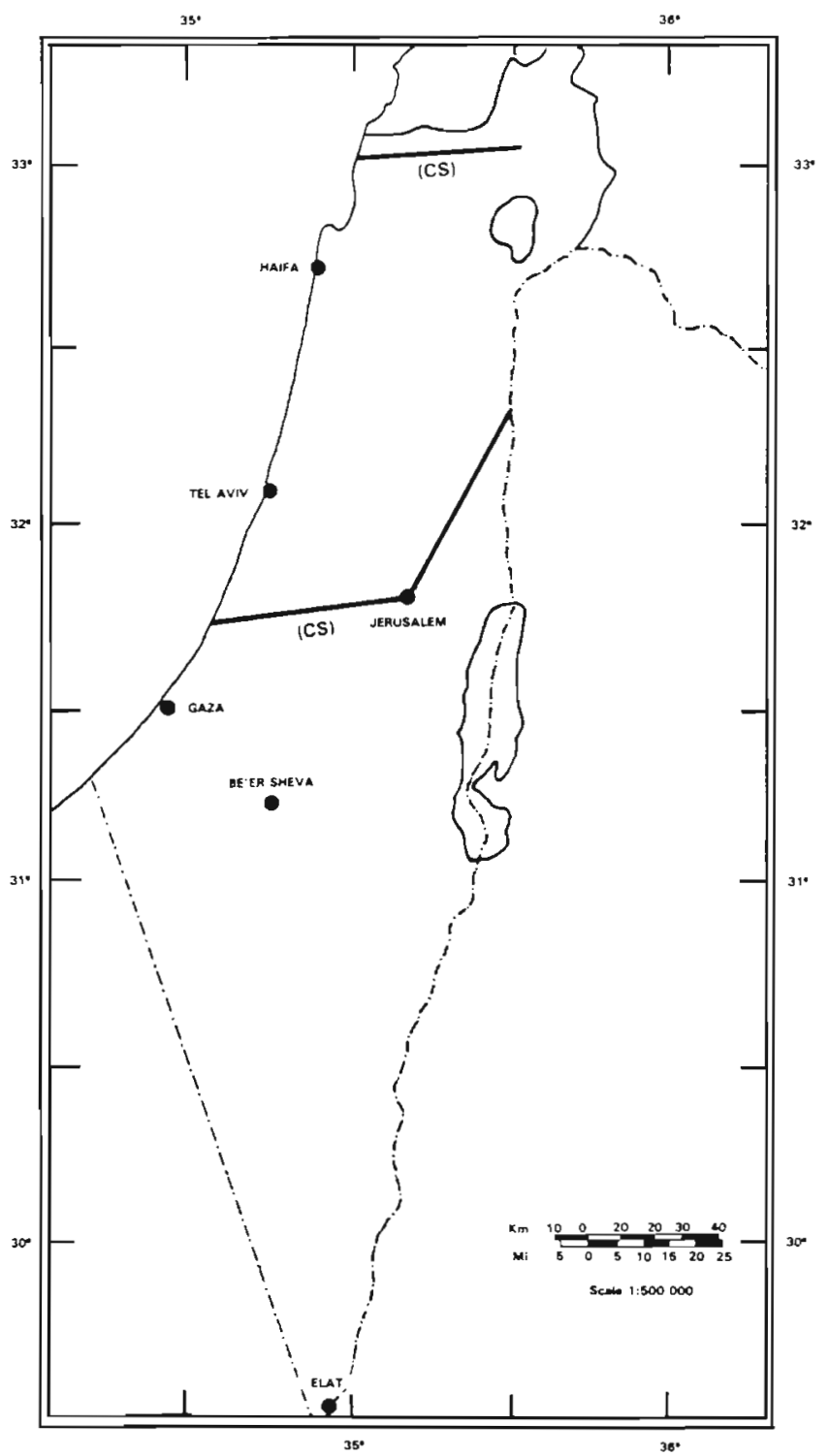

Fig. 6. Locations of cross sections (CS)

After an initial estimate of the chilling available at a given site is made, consideration should also be given to local environmental factors which may alter the effectiveness of chilling temperatures recorded in the atmosphere itself (Aron 1983).

Acknowledgements. We thank I-Ming Aron, Computer Services at Central Michigan University, for her assistance with computer applications, and also the Israeli Meteorological Service for providing the meteorological data.

\section{LITERATURE CITED}

Aron, R. H. (1971). Climatic chilling and future almond growing in Southern California. Prof. Geog. 23: 341-343

Aron, R. H. (1975). A method for estimating the number of

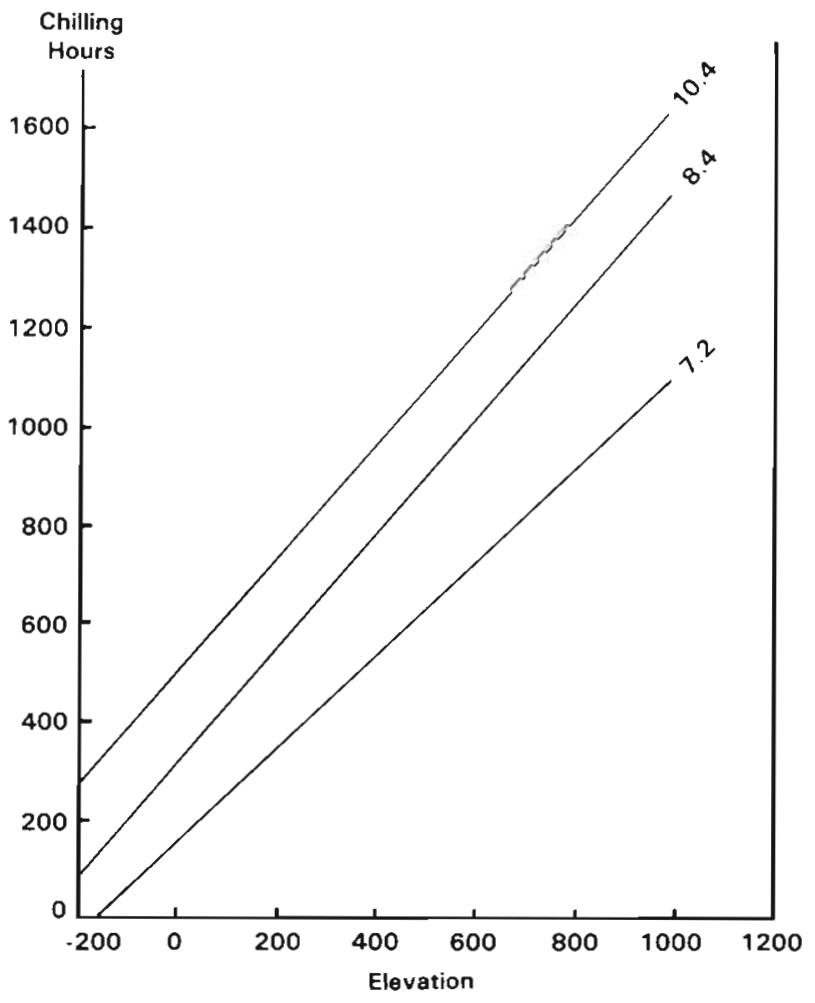

Fig. 7. Variation with elevation of 3 chilling temperature thresholds

hours below a selected temperature threshold. J. appl. Meteorol. 14: 1415-1418

Aron, R. H. (1983). Availability of chilling temperatures in California. Agric. Meteorol. 28: 351-363

Bennett, J. P. (1950). Temperature and bud rest period. Effect of temperature and exposure on the rest period of deciduous plant leaf buds investigated. Calif. Agric. 4: 12-16

Black, M. W. (1953). Problem of prolonged rest in deciduous fruit trees. 13th Int. Hort. Cong. 2: 1122-1131

Brown, D. S. (1958). The relation of temperature to the flower bud drop of peaches. Proc. Am. Soc. Hortic. Sci. 71: 77-87

Brown, D S. (1960). The relation of temperature of the growth of apricot flower buds. Proc. Am. Soc. Hortic. Sci. 75: 138-147

Butson, K. D., Gerber, J. F. (1964). Temperature hazards to peaches in Florida. Proc Fla. State Hortic. Soc. 77: 395-401

Chandler, W. H. (1957). Deciduous orchards. Lea and Febiger, Philadelphia

Cooper, J. R. (1953). Factors affecting winter injury to peach trees. Arkansas Exp. Stat. Bull. 536

Demaria, E. A. (1969). Carta estimada de horas de frio de la Republica Argentinia. Rev. Fac. Agron. Vet. Univ. Buenos Aires 17: 28-35

Erez, A., Couvillon, G. A. (1987). Characterization of the influence of moderate temperatures on rest completion in peach. Hort Science 112: 667-680

Erez, A., Lavee, S. (1971). The effect of climate conditions on dormancy development of peach buds. I. Temperature. J. Am. Soc. Hortic. Sci. 96: 711-714

Gilreath, P. R., Buchanan, D. W. (1981). Rest prediction model for low chilling 'sungold' nectarine. J. Am. Soc. Hortic. Sci. 106: $426-429$

Griffiths, John F. (1960). The number of hours below a chosen 
temperature threshold. (Unpublished paper, Texas A \& M University)

Gurdian, R. J., Biggs, R. H. (1964). Effect of low temperatures on terminating bud-dormancy of 'Okinawa', 'Flordawon and 'Nemaguard' peaches. Proc. Fla. Stat. Hortic. Soc. 77 $370-379$

Lamb, L. C. (1948). Effect of temperatures above and below freezing on the breaking of rest in the Latham raspberry. $\mathrm{J}$. Am. Soc. Hortic. Sci. 51: 313-315

Lomas, J., Gat, Z., Borsok,. Z., Raz, Z. (1989). Frost atlas of Israel. Israel Meteorological Service, Bet-Degan

Richardson, E. A., Seeley, S. D., Walker, D. R. (1974). A model for estimating the completion of rest for 'Redhaven' and 'Elberta' peach trees. HortScience 9: 331-333

Samish, R. M. (1954). Dormancy in woody plants. Ann. Rev. Plant Physiol. 5: 183-204

Sanders, C. G. (1975). Climatic chilling in Georgia. Georgia Agric. Res. 18: 19-22

Editor: V. Meentemeyer
Sharpe, R. H., Parker, R. (1963). Growing peaches in Florida. Univ. of Fla. Agric, Ext. Ser. Cir. 264

Tabuenca, M. C., Mut, M., Herrero, J. (1972). Influencia de la temperatura en la Epoca de Floracion de variedades de almendo. An. Estac. Exp. Aula Dei 11: 378-395

Weinberger, J. H. (1950). Chilling requirements of peach varieties. Proc. Am. Soc. Hortic. Sci. 56: 122-128

Weinberger, J. H. (1956). Prolonged dormancy trouble in peaches in the southeast in relation to winter temperatures. Proc. Am. Soc. Hortic. Sci. 67: 107-112

Weinberger, J. H. (1967). Some temperature relations in natural breaking of rest of peach flower buds in the San Joaquin Valley, California. Proc. Am. Soc. Hortic. Sci. 91: $84-89$

Westwood, M. N., Bjornstad, H. O. (1968). Chilling requirements of dormant seeds of 14 pear species as related to their climatic adaption. Proc. Am. Soc. Hortic. Sci. 92: 141-149

Manuscript first received: August 6, 1990

Revised version accepted: October 22, 1990 